IP $\rightleftharpoons$ B

\title{
Capture suggests the successful introduction of Sirex parasitoid in Brazil
}

\author{
Susete Rocio Chiarello Penteado ${ }^{1}$ (D), Edson Tadeu lede ${ }^{1}$ (D), Guilherme Schnell e Schühli ${ }^{*}$ (D) \\ 'Embrapa Florestas, Estrada da Ribeira, km 111, CP. 319, CEP 83411-000, Colombo, PR, Brazil
}

"Corresponding author:

guilherme.schuhli@embrapa.br

Index terms:

Megarhyssa nortoni

Woodwasp

Forest entomology

Termos para indexação:

Megarhyssa nortoni

Vespa-da-madeira

Entomologia florestal

Received in 05/06/2019

Accepted in 16/12/2019

Published in 07/05/2020

(c) $(1) \odot$

\begin{abstract}
Other organisms may be employed in the control of woodwasp besides the nematode Deladenus siricidicola. This is the case of the parasitoid Megarhyssa nortoni. Its introduction in Brazil occurred with a limited number of specimens and, so far, it has not been possible to assert its establishment. After 20 years from the introduction we have received reports that $M$. nortoni adults were captured in Santa Catarina. We identified in the samples several adults of the parasitoid which suggests their establishment in Brazilian territory.
\end{abstract}

\section{Captura sugere sucesso na introdução de um parasitóide de Sirex no Brasil}

\begin{abstract}
Resumo - Além do nematóide Deladenus siricidicola, outros organismos podem ser usados no controle da vespa-da-madeira, como o parasitoide Megarhyssa nortoni. Sua liberação no Brasil ocorreu com um número limitado de exemplares. Até o momento não havia evidências para assegurar seu estabelecimento. Depois de 20 anos da introdução recebemos relatos de que adultos de $M$. nortoni foram capturados em Santa Catarina. Nós identificamos vários adultos do parasitoide nas amostras deste material, o que sugere seu estabelecimento em território brasileiro.
\end{abstract}

The wood wasp Sirex noctilio Fabricius 1793 (Hymenoptera, Siricidae) was introduced in many countries where it is considered a pest of several species within the genus Pinus (Iede \& Zanetti, 2007). Since pine plantations in Brazil occupy 1.6 million ha (Indústria Brasileira de Árvores, 2017) the wood wasp damage has become part of the forestry sector's concerns. The impact of this insect damage in pine plantations in Brazil reached $60 \%$ (Iede \& Zanetti, 2007) and losses of 6.5 million dollars per year (Oliveira et al., 2013). A more recent evaluation estimated that the pest is affecting some $1 \mathrm{M}$ ha, causing US\$ 9 million per year of economic losses (Embrapa, 1989; Iede et al., 2015). In a country where $1.1 \%$ of gross domestic product (GDP) comes from the forestry sector, this amount of impact is very significant (Indústria Brasileira de Árvores, 2017).

Strategies aiming Sirex control recommend a combination of silvicultural and biological control measures (Haugen et al., 1990; Iede et al., 1998). Silvicultural treatments can preserve the health and vigor of pines preventing attacks. Management actions as timing selective thinning and restricting pruning and thinning-to-waste outside the wasp flight season can greatly reduce the attack risk (Carnegie et al., 2005).

As an initiative to protect the Pinus production chain, the National Program for wood wasp Control (Programa 
Nacional de Controle à Vespa da Madeira - PNCVM) was funded by Funcema (Fundo Nacional de Controle de Pragas Florestais). The program made possible to adapte and develope measures of prevention, monitoring, and control of the pest within the principles of the integrated pest management (IPM). The measures were based on the Australian biological control management system using Deladenus siricidicola (Bedding, 1968) (Nematoda, Neothylenchidae) which sterilizes female wood wasps, reaching levels of parasitism close to $100 \%$ (Iede et al., 1998). The Australian program has been a model for Sirex management in the pine-growing regions of the southern hemisphere since the 1960s (Williams \& Hajek, 2017). The adoption of these measures adapted to the Brazilian scenario allowed the maintenance of the pest population at controlled levels minimizing economic losses (Penteado et al., 2012).

Nonetheless, we also used in Brazil other organisms aiming to ensure a wider set of systemic tools. Potential natural biological control such as the parasitoids Ibalia leucospoides Hochenwarth, 1785, Rhyssa persuasoria (Linnaeus, 1758) and Megarhyssa nortoni (Cresson, 1864) (Hymenoptera, Ichneumonidae, Rhyssinae) were already known (Taylor, 1976; Penteado et al., 2012, 2016). Among the three parasitoids, M. nortoni was the most effective in the wood wasp population control when in association with $R$. persuasoria in Tasmania, Australia, with a significant reduction of the pest (Madden, 1988). The larval parasitoid M. nortoni is an ectoparasitoid and attacks wood wasp larvae during its later stages of development (Taylor, 1976). The females perforate the wood with their ovipositor until they find a larva of Sirex, which receives a sting and is paralyzed. An egg is placed on the host larva and it can hatch in two days, with the larva beginning its feeding on the body of the host. The larval period usually lasts three to five weeks (Hocking, 1968). Most of the individuals of each generation (about 80\%) enter diapause in the larval stage, when fully fed, thus presenting a cycle lasting two years. Those who do not enter diapause immediately pupate, with a cycle lasting three to four months (Taylor, 1976). The pupae are located close to the shell and the adults chew the wood to emerge, opening a hole through which they leave (Nutall, 1980).

The introduction of M. nortoni in Brazil occurred as a result of cooperation between the United States Department of Agriculture (USDA), the International Bureau of Biological Control (CABI-Bioscience) and the
University of Tasmania promoted by Empresa Brasileira de Pesquisa Agropecuária (Embrapa) (Penteado et al., 2015). The release occurred in two phases (Penteado et al., 2012, 2015), with a limited number of specimens released due to difficulties with the adaptation of the rearing process. The first phase covered seven releases in the state of Santa Catarina between 1997 and 1999. In 2003 a new strain was introduced and released in a municipality in the state of Paraná. In addition to the problems with the rearing process (and the small number of specimens released), the trees of one areas were felled the following year after the release (Penteado et al., 2015). Field assessment were carried out in October 2015 in pine plantations in Santa Catarina State, but there was no concrete evidence to ensure that $M$. nortoni introductions had been sufficient for the establishment success. These occurrences affected our expectation of success in the introduction of the parasitoid.

It was included in the procedures of the wood wasp control program a request for reports of the occasional captures of $M$. nortoni by the companies that maintain areas of pine plantations with wood wasp control practices. Due to these reports, in the last two years, Embrapa received accounts that $M$. nortoni's adults were being captured in the municipality of São José do Cerrito, in Santa Catarina State.

The companies have as a recommendation the record of parasitoid catches that emerge from control logs. Therefore, the captured specimens are normally released just after its record. Upon knowing of alleged $M$. nortoni occurrence we requested the collection of some vouchers directly preserved in ethanol $70^{\circ} \mathrm{GL}$. These samples were received identified with the collection date, geographic position, and collector. All samples were examined directly in ethanol under a stereomicroscope (80x zoom). Some of the samples were dry mounted with an entomological pin to be deposited as collection vouchers. Photographic images were taken directly with a reflex digital camera Canon EOS 1100D. We captured 15 pictures representing different levels of the focus of the mounted insect. Images were electronically aligned (under the option "align and balance") and stacked (under the option "weighted average") in Combine ZP (Hadley, 2010). Color levels were adjusted with the GNU Image Manipulation Program (GIMP... 2019). Dry mounted identified samples were deposited in the Entomological Collection Padre Jesus Santiago Moure, Department of Zoology, Federal University of Paraná 
(DZUP, Curitiba, Parana State, Brazil). Vouchers were also kept in the reference entomological collection of Embrapa Florestas (Colombo, Parana State, Brazil). Some comparative keys to hymenopteran parasitoids associated with Sirex were used as Schiff et al. (2006), Standley et al. (2012), Pook et al. (2016) to confirm identification. It should be mentioned that after the capture of these specimens the companies returned to release to the environment any live adults of $M$. nortoni captured from the control logs.

More than a hundred specimens were received all positively identified as $M$. nortoni originated from the municipality of São José do Cerrito $\left(27^{\circ} 39^{\prime} 45^{\prime \prime} \mathrm{S}\right.$, $\left.50^{\circ} 34^{\prime} 48^{\prime \prime} \mathrm{W}\right)$. Males and females were represented in sampled material (Figure 1). These catches coincide with the known adult emergence period and with the period when the wood wasp is at a more advanced stage of larval development (approximately from November to February).

This find is the first support to the hypothesis that populations of $M$. nortoni are indeed established in Brazilian territory. It is possible to infer that there is support capacity for the parasitoid maintenance in Brazil. Based on these finds we expect that mass production can be retaken as a promising aid tool in wood wasp control in addition to the standard use of the nematode in the PNCVM. This inclusion aims at the refinement of the processes of laboratory rearing and reintroduction in the $S$. noctilio occurrence areas in order to achieve even more effective control of the damages caused by the wood wasp.
Figure 1. Megarhyssa nortoni male and female specimens captured in Santa Catarina State, Brazil. Male, dorsal view (a); Female, dorsal view (b); Male, right lateral view (c) and Male, head frontal view (d).
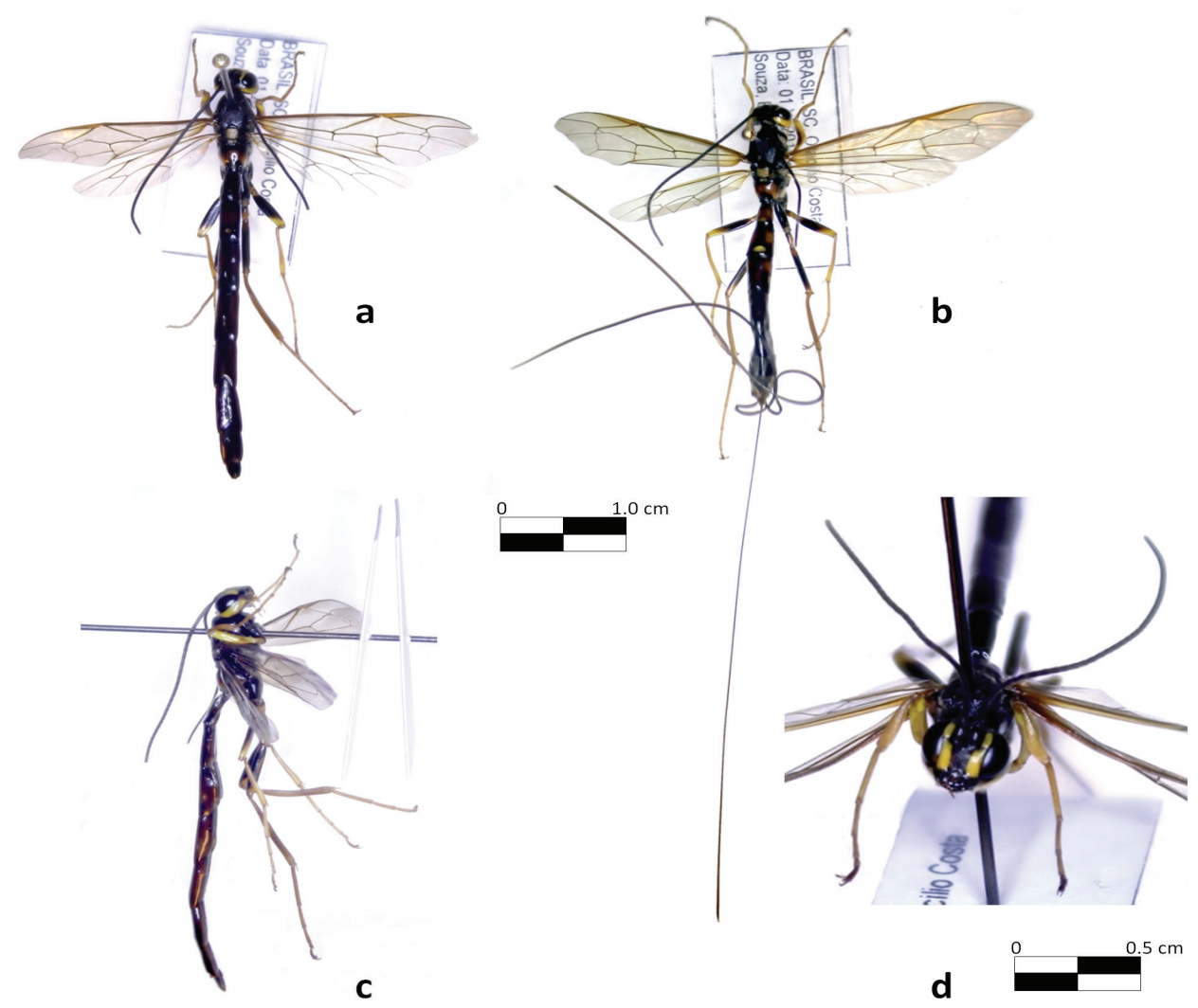

\section{Acknowledgments}

We thank the Fundo Nacional de Controle de Pragas Florestais/National Pest Control Fund (FUNCEMA) for contributing to the research related to the woodwasp control. We also would like to thanks the affiliated companies for the report and prompt scientific sample shipment. 


\section{References}

Bedding, R. A. Deladenus wilsoni $\mathrm{n}$. sp. and D. siricidicola $\mathrm{n} . \mathrm{sp}$. (Neotylenchidae), entomophagous-mycetophagous nematodes parasitic in siricid woodwasps. Nematologica, v. 14, p. 515-525, 1968. https://doi.org/10.1163/187529268X00200.

Carnegie, A. J. et al. History and management of Sirex wood wasp in pine plantations in new South Wales, Australia. New Zealand Journal of Forestry Science, v. 35, p. 3-24, 2005.

Embrapa: Empresa Brasileira de Pesquisa Agropecuária. Manejo integrado de pragas: vespa-da-madeira. Embrapa: Soluções tecnológicas, 1989. Available from: <https://www.embrapa.br/ busca-de-solucoes-tecnologicas/-/produto-servico/1518/manejointegrado-de-pragas-vespa-da-madeira $>$ Access on: 17 May 2019.

GIMP Image Editor. GNU Image Manipulation Program: GIMP. 2019. Available from: <http://www.gimp.org $>$. Access on: 14 May 2019.

Hadley, A. Combine ZP software: new version. 2010. Available from: <https://web.archive.org/web/20090123110407>. Access on: 14 May 2019.

Haugen, D. A. \& Underdown, M. G. Sirex noctilio control program in response to the 1987 Green Triangle outbreak. Australian Forestry, v. 53, p. 33-40, 1990.

Hocking, H. Studies on the biology of Rhyssa persuasorza (L.) (Hymenoptera : Ichneumonidae) incorporating an x-ray technique. Journal of the Australian Entomological Society, v. 7, p.1-5, 1968.

IBÁ. Indústria Brasileira de Árvores. Relatório $2017=$ Report 2017. Brasília, DF, 2017. 80 p. Available from: $<$ https://iba.org/ images/shared/Biblioteca/IBA_RelatorioAnual2017.pdf $>$. Access on: 14 May 2019.

Iede, E. T. \& Zanetti, R. Ocorrência e recomendações para o manejo de Sirex noctilio Fabricius (Hymenoptera, Siricidae) em plantios de Pinus patula (Pinaceae) em Minas Gerais, Brasil. Revista Brasileira de Entomologia v. 51, p. 529-531, 2007.

Iede, E.T. et al. Vespa-da-madeira, Sirex noctilio Fabricius. In: Vilela, E.F. \& Zucchi, R.A. (Ed.) Pragas introduzidas no Brasil: insetos e ácaros. Piracicaba, SP: FEALQ, 2015. p. 810-826.

Iede, E. T. et al. Programa nacional de controle a vespa-da-madeira no Brasil. In: TRAINING IN THE CONTROL OF SIREX NOCTILIO BY THE USE OF NATURAL ENEMIES. Colombo. Proceedings... Morgantown: USDA Forest Service, 1998. p. 43-51.
Madden, J. L. Sirex in Australia. In: Berryman, A. (Ed.) A Dynamics of forest insect populations. New York: Plenum Press, 1988. p. 407-427.

Nuttal, M. J. Deladenus siricidicola Bedding (Nematoda: Neotylenchidae) nematode parasite of sirex. Rotorua: Forest Research Institute, New Zealand Forest Service, 1980. p. 30. (Forest and Timber Insects in New Zeland, 48).

Oliveira, C. M. et al. Economic impact of exotic insect pests in Brazilian agriculture. Journal of Applied Entomology, v. 137, p.1-15, 2013.

Penteado, S. R. C. et al. Manual para o controle da vespa-damadeira em plantios de pínus. Colombo: Embrapa Florestas, 2015. 43 p. (Embrapa Florestas. Documentos, 76).

Penteado, S. R. C. et al. Programa Nacional de Controle à Vespa-daMadeira. In: SEMINÁRIO INTERNACIONAL SOBRE PRAGAS QUARENTENÁRIAS FLORESTAIS, 2012, Colombo. Anais... Colombo: Embrapa Florestas, 2012. p. 53-58 (Embrapa Florestas. Documentos, 244). Disponível em: <http://www.alice.cnptia. embrapa.br/alice/handle/doc/951680>.

Penteado, S. R. C.et al. Sample size for monitoring sirex populations and their natural enemies. Pesquisa Florestal Brasileira, v. 36, n. 87, p. 297-301, 2016. https://doi.org/10.4336/2016.pfb.36.87.788.

Pook, V. G. et al. Key to the Species of Megarhyssa (Hymenoptera, Ichneumonidae, Rhyssinae) in America, North of Mexico. Deutsche Entomologische Zeitschrift, v. 63, p. 137-148, 2016.

Schiff, N. M. et al. Guide to the siricid woodwasps of North America. Morgantown: Forest Service, Forest Health Technology Enterprise Team, 2006. 102 p.

Standley, C. R. et al. Detection and identification of two new native hymenopteran parasitoids associated with the exotic Sirex noctilio in North America. Proceedings of the Entomological Society of Washington, v. 114, p. 238-249, 2012.

Taylor, K. L. The introduction and establishment of insect parasitoids to control Sirex noctilio in Australia. Entomophaga, v. 21, p. 429440, 1976.

Williams, D. W. \& Hajek, A. E. Biological control of Sirex noctilio (Hymenoptera: Siricidae) in the northeastern United States using an exotic parasitic nematode. Biological Control, v. 107, p. 77-86, 2017. 